\title{
Novel low-temperature sintering ceramic substrate based on indialite/cordierite glass ceramics
}

\author{
Jobin Varghese $^{* 1}$, Timo Vahera ${ }^{1}$, Hitoshi Ohsato ${ }^{1,2}$, Makoto Iwata, ${ }^{3}$ and Heli Jantunen ${ }^{1}$ \\ ${ }^{1}$ Microelectronics Research Unit, Faculty of Information Technology and Electrical Engineering, \\ University of Oulu, Oulu 90014, Finland \\ ${ }^{2}$ Nagoya Industrial Science Research Institute, Nagoya 464-0819, Japan \\ ${ }^{3}$ Nagoya Institute of Technology, Nagoya 466-8555, Japan
}

\begin{abstract}
In this paper, a novel low-temperature sintering substrate for low temperature co-fired ceramic applications based on indialite/cordierite glass ceramics with $\mathrm{Bi}_{2} \mathrm{O}_{3}$ as a sintering aid showing low permittivity $\left(\varepsilon_{\mathrm{r}}\right)$ and ultralow dielectric $\operatorname{loss}(\tan \delta)$ is described. The fine powder of indialite was prepared by the crystallization of cordierite glass at $1000{ }^{\circ} \mathrm{C} / 1 \mathrm{~h}$. The optimized sintering temperature was $900{ }^{\circ} \mathrm{C}$ with $10 \mathrm{wt} \% \mathrm{Bi}_{2} \mathrm{O}_{3}$ addition. The relative density achieved was $97 \%$, and $\varepsilon_{\mathrm{r}}$ and $\tan \delta$ were 6.10 and 0.0001 at $1 \mathrm{MHz}$, respectively. The composition also showed a moderately low temperature coefficient of relative permittivity of $118 \mathrm{ppm} /{ }^{\circ} \mathrm{C}$ at $1 \mathrm{MHz}$. The obtained linear coefficient of thermal expansion was $3.5 \mathrm{ppm} /{ }^{\circ} \mathrm{C}$ in the measured temperature range of $100-600{ }^{\circ} \mathrm{C}$. The decreasing trend in dielectric loss, the low relative permittivity at $1 \mathrm{MHz}$, and the low thermal expansion of the newly developed composition make it an ideal choice for radio frequency applications.
\end{abstract}

\section{Introduction}


Recently, low-temperature cofired ceramic (LTCC) materials have combined the advantages of multilayer ceramic and thick film technologies to meet the increasing need for electronics running at extreme operating temperatures and in other harsh environments. ${ }^{1-5)}$ The low dielectric loss characteristics of the LTCC make it an excellent choice for high-frequency applications and enable circuits and devices that are more efficient. ${ }^{6-15)}$ These materials should have low permittivity $\left(\varepsilon_{\mathrm{r}}<\right.$ 10), low dielectric loss $\left(\tan \delta \sim 10^{-3}\right)$, and a low-temperature dependence of resonant frequency (TCf $\left.<20 \mathrm{ppm} /{ }^{\circ} \mathrm{C}\right) .^{3,16-18)}$ This is because the low relative permittivity increases the signal speed ${ }^{3,19-23)}$, and the low dielectric loss minimizes the insertion loss and enables highly selective circuits and applications. ${ }^{3,24-25)}$ Furthermore, the near-zero temperature stability of dielectric properties enables the frequency and insertion loss stability of the devices. ${ }^{26-28)}$

Ohsato et al. ${ }^{29)}$ reported in 2011 indialite/cordierite $\left(\mathrm{Mg}_{2} \mathrm{Al}_{4} \mathrm{Si}_{5} \mathrm{O}_{18}\right)$ glass ceramics crystallized at 1200 to $1400{ }^{\circ} \mathrm{C}$ for 10 and $20 \mathrm{~h}$. Indialite/cordierite is one of the silicates reported to have excellent properties being suitable for microwave and millimeter-wave applications owing to its low relative permittivity ( $\varepsilon_{\mathrm{r}}$ of 4.7$)$ and high quality factor $(Q f>200,000 \mathrm{GHz}) .{ }^{30)}$ However, the high crystallization temperature of these glass ceramics limits their feasibility to LTCC packages. This paper focus on the development of indialite/cordierite glass ceramics with $\mathrm{Bi}_{2} \mathrm{O}_{3}$ as the sintering aid, which provides liquid-phase-assisted densification for the developed LTCC substrates. The paper also describes the tape casting, firing, and dielectric properties of the developed LTCC composition.

\section{Experimental methods}

The primary cordierite/indialite $\mathrm{Mg}_{2} \mathrm{Al}_{4} \mathrm{Si}_{5} \mathrm{O}_{18}$ composition was based on Ohsato's previously published article. ${ }^{30)}$ The composition was melted at $1550{ }^{\circ} \mathrm{C}$, refined at $1600{ }^{\circ} \mathrm{C} / 1 \mathrm{~h}$, and crushed roughly to a particle size below $1 \mathrm{~mm}$. This was followed by the crystallization of the indialite phase at $1000{ }^{\circ} \mathrm{C} / 1 \mathrm{~h}^{31)}$ and ball milling to reduce the particle size. The sintering aid $\mathrm{Bi}_{2} \mathrm{O}_{3}$ (high-purity (99\%) $\mathrm{Bi}_{2} \mathrm{O}_{3}$; Alfa Aesar) was added at 5, 10, 15, and $20 \mathrm{wt} \%$ to the processed indialite powder, 
followed by pelletization using a $14 \mathrm{~mm}$ diameter tungsten carbide cylindrical die with a pressure of $100 \mathrm{MPa}$ from a uniaxial pressing unit. The initial particle size and surface area analyses of the powder were performed using the laser diffraction method (Beckman Coulter, LS13320) as well as a particle surface area analyzer (G.W. Berg \& Co; Micrometrics ASAP 2020). The tape casting slurry was made using xylene (ACS reagent 98.5 wt\% xylene ethyl benzene)/ethanol (Etax Aa 99.5 wt\% ethanol) as the solvent system, menhaden fish oil (Blown Menhaden fish oil grade Z-3) as the dispersant, poly(vinyl butyral) (PVB; Butvar B98) as the binder, and butyl benzyl phthalate (BBP; Santicizer S160) and poly ethylene glycol (PEG; UCON50HB2000) as plasticizers. The ceramic powder was mixed with the solvent and dispersant by ball milling for around $20 \mathrm{~h}$, followed by the addition of the binder and plasticizers and further milling for approximately $24 \mathrm{~h}$. Finally, the slurry was cast onto a silicone-coated Mylar carrier tape using a $400 \mu \mathrm{m}$ doctor blade. The cast tape was peeled off the Mylar film, followed by subsequent lamination with uniaxial pressing before binder burnout and sintering.

The crystal structure of the specimen was analyzed by X-ray powder diffraction (XRPD; Bruker D8) using monochromatized $\mathrm{Cu} \mathrm{K \alpha}$ radiation. The bulk densities of the sintered samples were measured by the Archimedes method. The microstructural analysis of the thermally etched tape samples was performed by scanning electron microscopy (FESEM; Zeiss Ultra Plus). The temperature coefficient of relative permittivity $(T C \varepsilon)$ was measured using a precision LCR meter (Hewlett-Packard/Agilent Technologies 4284A) with a temperature chamber (Espec; SU-261) in the temperature range of -40 to $100^{\circ} \mathrm{C}$. The relative permittivity and dielectric loss in the frequency range of $100 \mathrm{~Hz}-1 \mathrm{MHz}$ were measured using the same LCR meter. The coefficient of thermal expansion $(C T E)$ was investigated in the temperature range of $100-600{ }^{\circ} \mathrm{C}$ with cylindrical samples of $8 \times 15 \mathrm{~mm}^{2}$ dimensions using a dilatometer (NETZSCH DIL $\left.402 \mathrm{PC} / 4\right)$.

\section{Results and discussion}


Figure 1(a) shows the XRPD patterns of 5, 10, 15, and $20 \mathrm{wt} \% \mathrm{Bi}_{2} \mathrm{O}_{3}$-added indialite powder samples sintered at $900{ }^{\circ} \mathrm{C}$ for $2 \mathrm{~h}$. The results indicate that, after the addition of $5 \mathrm{wt} \% \mathrm{Bi}_{2} \mathrm{O}_{3}$, the major phase is indialite, while with $10-20 \mathrm{wt} \%$ addition, the secondary phase $\mathrm{Bi}_{2} \mathrm{SiO}_{5}$ appears. All the peaks are indexed with standard ICDD card numbers $01-082-1542$ for $\mathrm{Mg}_{2} \mathrm{Bi}_{0.168}\left(\mathrm{Al}_{4} \mathrm{Si}_{5} \mathrm{O}_{18}\right)$ and 04-019-9380 for $\mathrm{Bi}_{2} \mathrm{SiO}_{5}$. It was observed that, when the $\mathrm{Bi}_{2} \mathrm{O}_{3}$ content increased, the $\mathrm{Bi}_{2} \mathrm{SiO}_{5}$ phase was more prominent after sintering at $900{ }^{\circ} \mathrm{C}$.

The best dopant level was optimized based on dielectric properties and densification. Figure 1(b) shows the $\varepsilon_{r}$ and $\tan \delta$ of the samples sintered at $900{ }^{\circ} \mathrm{C} / 2 \mathrm{~h}$ using $5-20 \mathrm{wt} \% \mathrm{Bi}_{2} \mathrm{O}_{3}$-added indialite ceramics at $1 \mathrm{MHz}$. It is evident from Fig. 1(b) that $\varepsilon_{\mathrm{r}}$ increases from 5.7 to 9.9 and $\tan \delta$ first decreases from 0.004 to 0.0001 and then increases from 0.0001 to 0.0007 owing to the increasing secondary phase $\mathrm{Bi}_{2} \mathrm{SiO}_{5}$. Thus, the suitable composition from the viewpoint of dielectric properties is achieved by the addition of $10 \mathrm{wt} \% \mathrm{Bi}_{2} \mathrm{O}_{3}$ with $\varepsilon_{\mathrm{r}}=6.10$ and $\tan \delta=0.0001 \mathrm{at} 1 \mathrm{MHz}$. Figure 1(c) shows the densification of $10 \mathrm{wt} \% \mathrm{Bi}_{2} \mathrm{O}_{3}$-added indialite at sintering temperatures of $850-950{ }^{\circ} \mathrm{C} / 2 \mathrm{~h}$. The sample sintered at $900{ }^{\circ} \mathrm{C}$ showed good densification of $97 \%$. The backscattered electron image of this sample sintered at $900{ }^{\circ} \mathrm{C}$ with a high-density microstructure is shown in the inset of Fig. 1(c). Indialite grains are surrounded by bright areas that are detected to be $\mathrm{Bi}_{2} \mathrm{SiO}_{5}$ after cooling. Thus, during sintering, $\mathrm{Bi}_{2} \mathrm{O}_{3}$ is expected to melt at $830{ }^{\circ} \mathrm{C}$, enabling liquid phase densification ${ }^{32)}$. The $\mathrm{Bi}_{2} \mathrm{SiO}_{5}$ phase is also formed by crystallization from the melt that dissolves part of indialite at $900{ }^{\circ} \mathrm{C}$ as shown in a $\mathrm{Bi}_{2} \mathrm{O}_{3}-\mathrm{SiO}_{2}$ binary metastable phase diagram by Fei et al ${ }^{33)}$ At higher sintering temperatures, the slight decrease in densification may be due to the slight evaporation of $\mathrm{Bi}_{2} \mathrm{O}_{3}$ or the secondary phase observed by XRPD. From the dielectric properties and densification measurement results, the low-temperature sintering conditions for substrate fabrication with tape casting were selected to be $10 \mathrm{wt} \% \mathrm{Bi}_{2} \mathrm{O}_{3}$ and a sintering temperature of $900{ }^{\circ} \mathrm{C} / 2 \mathrm{~h}$. 
For the next step, the authors fabricated low-temperature sintering ceramic substrates with 5 layers for LTCC. The initial average particle size of the ceramic mixture $\left(10 \mathrm{wt} \% \mathrm{Bi}_{2} \mathrm{O}_{3}\right.$-added indialite) was $2.9 \mu \mathrm{m}$, and the single-point surface area at $\mathrm{P} / \mathrm{P}_{\mathrm{o}}=0.1998$ was $15.52 \mathrm{~m}^{2} / \mathrm{g}$. From these results, the slurry compositions were calculated as reported earlier. ${ }^{34)}$ The final tape casting slurry compositions are shown in Table I.

Figure 2 shows the photographs of the cast green tape (a), five-layers thermally laminated tape (b), and sintered substrate (c). The cast tape had a single layer thickness of about 120-130 $\mu \mathrm{m}$, which is mechanically stable for further thermolamination postprocessing. Figure 2(b) depicts the thermally laminated five-layer stack before shaping the edges with an approximate thickness of 600 $\mu \mathrm{m}$. The thermally laminated tape was carefully shaped and sintered at $900{ }^{\circ} \mathrm{C} / 2 \mathrm{~h}$ with its optimized sintering temperature. The sintered substrate (c) showed densification with a flat surface and no cracking.

Figure 3(a) shows the cross-sectional microstructure of a peeled off single layer of green tape with an average thickness of $120 \mu \mathrm{m}$. A magnified microstructural view in Fig. 3(b) reveals the good packing density of a single-layer green tape with a maximum ceramic mixture loading of 55 wt\% surrounded by an organic matrix (see Table I). Figure 3(c) shows the crosssection of the 10 $\mathrm{wt} \% \mathrm{Bi}_{2} \mathrm{O}_{3}$-added indialite substrate with an average thickness of $500 \mu \mathrm{m}$, which was sintered at $900{ }^{\circ} \mathrm{C}$. Figure $3(\mathrm{~d})$ shows the magnified view of the substrate showing the high-density sintering of the indialite dark and $\mathrm{Bi}_{2} \mathrm{SiO}_{5}$ bright phases without pores.

Figure 4(a) shows the dielectric properties of the $10 \mathrm{wt} \% \mathrm{Bi}_{2} \mathrm{O}_{3}$-added indialite sintered at $900{ }^{\circ} \mathrm{C}$ in the frequency range of $100 \mathrm{~Hz}-1 \mathrm{MHz}$. Note that the developed substrates showed decreases in relative permittivity and dielectric loss with increasing frequency in the range from 100 $\mathrm{Hz}$ to $1 \mathrm{MHz}$. The substrates also showed an excellent low relative permittivity of $6.35 \mathrm{at} 100 \mathrm{~Hz}$ and a decreased permittivity of 6.10 at $1 \mathrm{MHz}$. This relative permittivity is higher than that expected for pure indialite because of the existing secondary $\mathrm{Bi}_{2} \mathrm{SiO}_{5}$ phase. There was no report on the 
dielectric properties of $\mathrm{Bi}_{2} \mathrm{SiO}_{5}$ since it is a metastable phase. ${ }^{33)}$ Similarly, the dielectric loss decreased from 0.01 to 0.0001 with the frequency. The dielectric loss of this proposed composition at $1 \mathrm{MHz}$ is ultralow compared with the values reported for commercial LTCCs. ${ }^{35)}$ The dielectric loss of the developed substrate is larger than that of indialite owing to the presence of a secondary phase, because a single phase is better than a composite.

Figure 4(b) shows the variations in dielectric properties at $1 \mathrm{MHz}$ in the measured temperature range of -40 to $100{ }^{\circ} \mathrm{C}$. Note that relative permittivity and dielectric loss increased with temperature. The relative permittivity variation was about $1.6 \%$, while dielectric loss variation ranged from 0.00002 to 0.002 . The developed low-temperature sintering substrate exhibited a temperature coefficient of relative permittivity $(T C \varepsilon)$ of about $118 \mathrm{ppm} /{ }^{\circ} \mathrm{C}$. The low-temperaturesintered substrate with $\varepsilon_{\mathrm{r}}=6.10$ and $\tan \delta=0.00014$ at $1 \mathrm{MHz}$ is an ideal candidate for LTCC applications. Figure 5 shows the thermal expansion $(C T E)$ of $3.5 \mathrm{ppm} /{ }^{\circ} \mathrm{C}$ at 100 to $600{ }^{\circ} \mathrm{C}$, which is lower values than those of other materials such as alumina $\left(8.1 \mathrm{ppm} /{ }^{\circ} \mathrm{C}\right)$ and quartz $\left(8-14 \mathrm{ppm} /{ }^{\circ} \mathrm{C}\right)$. $T C f$ was calculated to be $-62.5 \mathrm{ppm} /{ }^{\circ} \mathrm{C}$ using the equation $T C f=-[T C E+T C \varepsilon / 2] .^{36)}$ This paper is the first step towards new low permittivity and dielectric loss, and new LTCC substrates even for higher frequency solutions.

\section{Conclusions}

A novel low-temperature-sintered microwave dielectric material with $\varepsilon_{\mathrm{r}}=6.10$ and $\tan \delta=0.0001$ at $1 \mathrm{MHz}$ was developed using $10 \mathrm{wt} \%-\mathrm{Bi}_{2} \mathrm{O}_{3}$ added indialite powder crystallized at $1200{ }^{\circ} \mathrm{C}$ for $1 \mathrm{~h}$. The material composed of indialite and $\mathrm{Bi}_{2} \mathrm{SiO}_{5}$ was sintered at a relative density of $97 \%$. A lowtemperature sintering substrate was fabricated using a caste green tape with $10 \mathrm{wt} \% \mathrm{Bi}_{2} \mathrm{O}_{3}$-added indialite with a binder and plasticizers, followed by thermo-lamination and sintering. The developed substrate showed a low relative permittivity of 6.10 , an ultralow dielectric loss of 0.00014 , and a $T C \varepsilon$ of $118 \mathrm{ppm} /{ }^{\circ} \mathrm{C}$ at $1 \mathrm{MHz}$. They also showed a $C T E$ of $3.5 \mathrm{ppm} /{ }^{\circ} \mathrm{C}$ in the measured temperature 
range of 100-600 ${ }^{\circ} \mathrm{C}$. The developed substrate for LTCC suggests that it might be an ideal choice for radio frequency applications.

\section{Acknowledgements}

The authors are thankful to Professor Isao Kagomiya of Nagoya Institute of Technology, Professors Hirotaka Ogawa and Akinori Kan of Meijo University, and President Sadahiko Suzuki of Marusu Glaze Co., Ltd. for the preparation of the indialite/cordierite powder. Dr. Hitoshi Ohsato is grateful to JSPS KAKENHI Grant Number JP16K06735 and Nokia Foundation 2016 for supporting this work for Nokia Visiting Professors Project 201700003. Professor Heli Jantunen and Dr. Jobin Varghese are grateful to European Research Council Project No. 24001893 for financial assistance. 


\section{References}

1. M. T. Sebastian, and H. Jantunen, Int. Mater. Rev. 53, 57 (2008).

2. J. Varghese, Zircon Based Hard, Soft Microwave Substrates, and Devices (Lambert Academic, Moldova, 2017) Chap. 1.

3. M. T. Sebastian, and H. Jantunen, in Microwave Materials and Applications ed. M. T. Sebastian, R. Ubic, and H. Jantunen (Wiley, New York, 2017) Vol. 1, Chap. 8.

4. A. Rydosz, W. Maziarz, J. Pisarkiewicz, H. Bartsch, and J. Muller, Int. J. Inf. Electr. Eng. 6, 143 (2016).

5. S. Bierlich, T. Reimann, St. Barth, B. Caprato, H. Bartsch, J. Muller, and J. Topfer, Int. J. Appl. Ceram. Technol. 13, 540 (2016).

6. D. Thomas, P. Abhilash, and M. T. Sebastian, J. Eur. Ceram. Soc. 33, 87 (2013).

7. P. Abhilash, M. T. Sebastian, and K. P. Surendran, J. Eur. Ceram. Soc. 35, 2313 (2015).

8. S. Arun, M.T. Sebastian, and K.P. Surendran, Ceram. Intr. 43, 5509 (2017).

9. I. J. Induja, K. P. Surendran, M. R. Varma, and M. T. Sebastian, Ceram. Intr. 43, 736 (2017).

10. G. Subodh, and M. T. Sebastian, J. Amer. Ceram. Soc. 90, 2266 (2007).

11. J. Honkamo, H. Jantunen, G. Subodh, M. T. Sebastian, and P. Mohanan, Intr. J. Appl. Ceram. Tech. 6, 531 (2009).

12. G. Subodh, and M. T. Sebastian, Jpn. J. Appl. Phys. 47, 7943 (2008).

13. A. N. Unnimaya, E. K. Suresh, and R. Ratheesh. Mater. Res. Bull. 88, 174 (2017).

14. E. K. Suresh, K. Prasad, N. S. Arun, and R. Ratheesh. J. Electron. Mater. 45, 2996 (2016).

15. M. Ando, H. Ohsato, D. Igimi, Y. Higashida, A. Kan, S. Suzuki, Y. Yasufuku, and I. Kagomiya, Jpn. J. Appl. Phys. 54, 10NE03 (2015).

16. H. Ohsato, J. Ceram. Soc. Jpn. 113, 703 (2005).

17. H. Ohsato, MRS Proc. 833, 55 (2005). 
18. H. Ohsato, T. Tsunooka, M. Ando, Y. Ohishi, Y. Miyauchi, and K. Kakimoto, J. Korean Ceram. Soc. 40, 350 (2003).

19. N. Kostylev, M. Goryachev, A. D. Bulanov, V. A. Gavva, and M. E. Tobar, Sci. Rep. 7, 44813 (2017).

20. M. Terada, K. Kawamura, I. Kagomiya, K. Kakimoto, and H. Ohsato, J. Eur. Ceram. Soc. 27, 3045 (2007).

21. H. Ohsato, M. Terada, and K. Kawamura, Jpn. J. Appl. Phys. 51, 09LF02 (2012).

22. I. Kagomiya, I. Suzuki, and H. Ohsato, Jpn. J. Appl. Phys. 48, 09KE02 (2009).

23. H. Ohsato, I. Suzuki, and I. Kagomiya, Mater. Res. Bull., In press, December (2016) DOI: 10.1016/j.materresbull.2016.12.020.

24. M. Ando, K. Himura, T. Tsunooka, I. Kagomiya, and H. Ohsato, Jpn. J. Appl. Phys. 46, 7112 (2007).

25. M. Ando, H. Ohsato, I. Kagomiya, and T. Tsunooka, Jpn. J. Appl. Phys. 47, 7729 (2008).

26. T. Tsunooka, M. Ando, S. Suzuki, Y. Yasufuku, and H. Ohsato, Jpn. J. Appl. Phys. 52, 09KH02 (2013).

27. T. Tsunooka, H. Sugiyama, K. Kakimoto, H. Ohsato, and H. Ogawa, J. Ceram. Soc. Jpn. 112, S1637 (2004).

28. H. Ohsato, M. Ando, and T. Tsunooka, J. Korean Ceram. Soc. 44, 597 (2007).

29. H. Ohsato, J. S. Kim, A.Y. Kim, C. I. Cheon, and K.W. Chae, Jpn. J. Appl. Phys. 50, 09NF01 (2011).

30. H. Ohsato, in Microwave Materials and Applications, ed. M.T. Sebastian, R. Ubic, and H. Jantunen (Wiley, New York, 2017) Vol. 1, Chap. 5.

31. H. Ohsato, J. S. Kim, C. I. Cheon, and I. Kagomiya, Ceram. Inter. 41, S588 (2015).

32. R. M. German, P. Suri, and S. J. Park, J. Mater. Sci. 44, 1, (2009). 
33. Y. T. Fei, S. J. Fan, R. Y. Sun, and M. Ishii, Prog. Cryst. Growth Charact. Mater. 40, 183 (2000).

34. R. E. Mistler, and E. R. Twiname, Tape Casting, Theory and Practice (American Ceramic Society, Westerville, OH, 2000) Appendix 1.

35. http://www.murata.com/ /media/webrenewal/support/library/catalog/products/substrate/lt cc/n20e.ashx (Accessed June 27, 2017).

36. M. T. Sebastian, Dielectric Materials for Wireless Communications (Elsevier, Amsterdam, 2008) Chapter 1. 


\section{Table and figure captions}

Table I Tape casting slurry composition.

Fig. [1.] (Color online) X-ray diffraction patterns (a), dielectric properties of indialite added with 5, 10,15 , and $20 \mathrm{wt} \% \mathrm{Bi}_{2} \mathrm{O}_{3}$ after sintering at $900{ }^{\circ} \mathrm{C}(\mathrm{b})$, and densification of indialite with $10 \mathrm{wt} \%$ $\mathrm{Bi}_{2} \mathrm{O}_{3}$ at different sintering temperatures (c) with inset representing backscattering image of the 10 $\mathrm{wt} \% \mathrm{Bi}_{2} \mathrm{O}_{3}$-added sample after sintering at $900{ }^{\circ} \mathrm{C} / 2 \mathrm{~h}$.

Fig. [2.] (Color online) Photograph of cast green tape (a), five-layer laminated multilayer substrate (b), and sintered substrate at $900{ }^{\circ} \mathrm{C}(\mathrm{c})$.

Fig. [3.] (Color online) Cross-sectional microstructure of $10 \mathrm{wt} \% \mathrm{Bi}_{2} \mathrm{O}_{3}$-added indialite green single-layer tape (a) and its magnified view (b), and cross section of a five-layer sample sintered at $900{ }^{\circ} \mathrm{C}(\mathrm{c})$ and its magnified view (d).

Fig. [4.] Variation in relative permittivity and dielectric loss tangent as a function of frequency (a), and temperature at $1 \mathrm{MHz}(\mathrm{b})$.

Fig. [5.] Thermal expansion of $10 \mathrm{wt} \% \mathrm{Bi}_{2} \mathrm{O}_{3}$-added indialite substrate as a function of temperature. 
Table I

\begin{tabular}{cc}
\hline Materials & $\begin{array}{c}\text { Composition } \\
(\mathbf{w t} \%)\end{array}$ \\
\hline Indialite+10 $\mathrm{wt} \% \mathrm{Bi}_{2} \mathrm{O}_{3}$ & 55 \\
Xylene/ethanol $(1: 1)$ & $(18.75: 18.75)$ \\
Fish oil & 1.4 \\
PVB & 4 \\
BBP & 1 \\
PEG & 1 \\
\hline
\end{tabular}



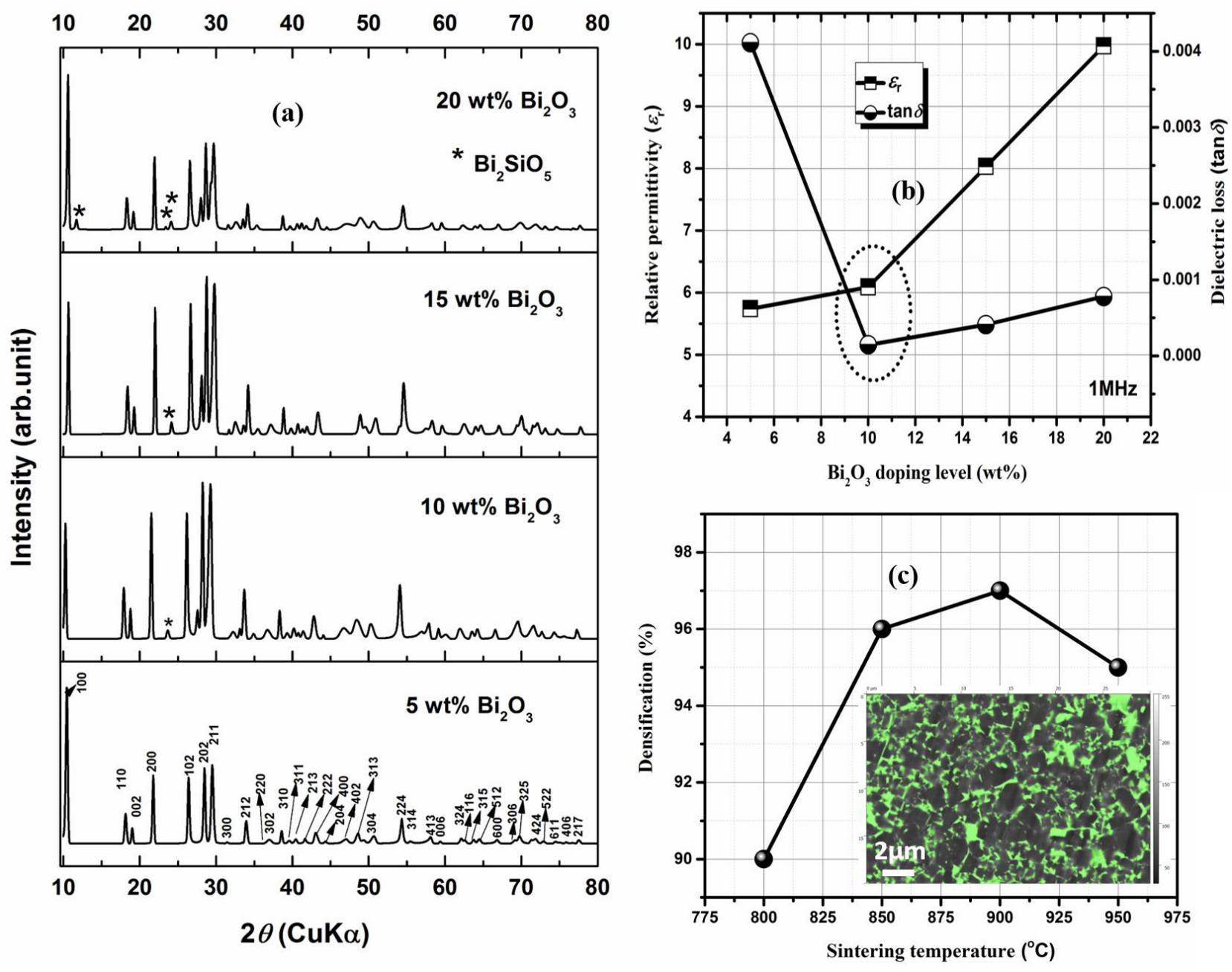

Fig. 1 


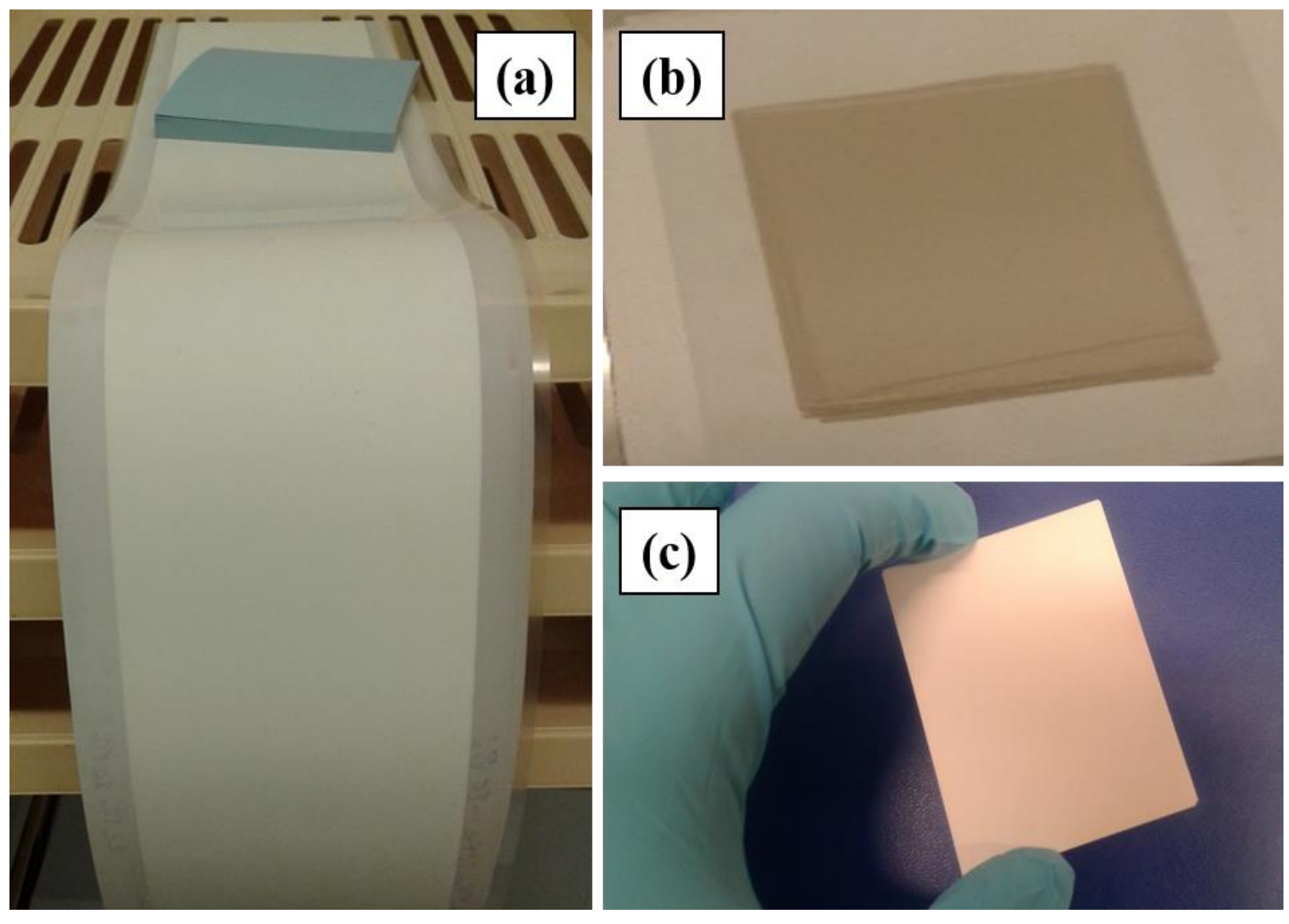

Fig. 2 

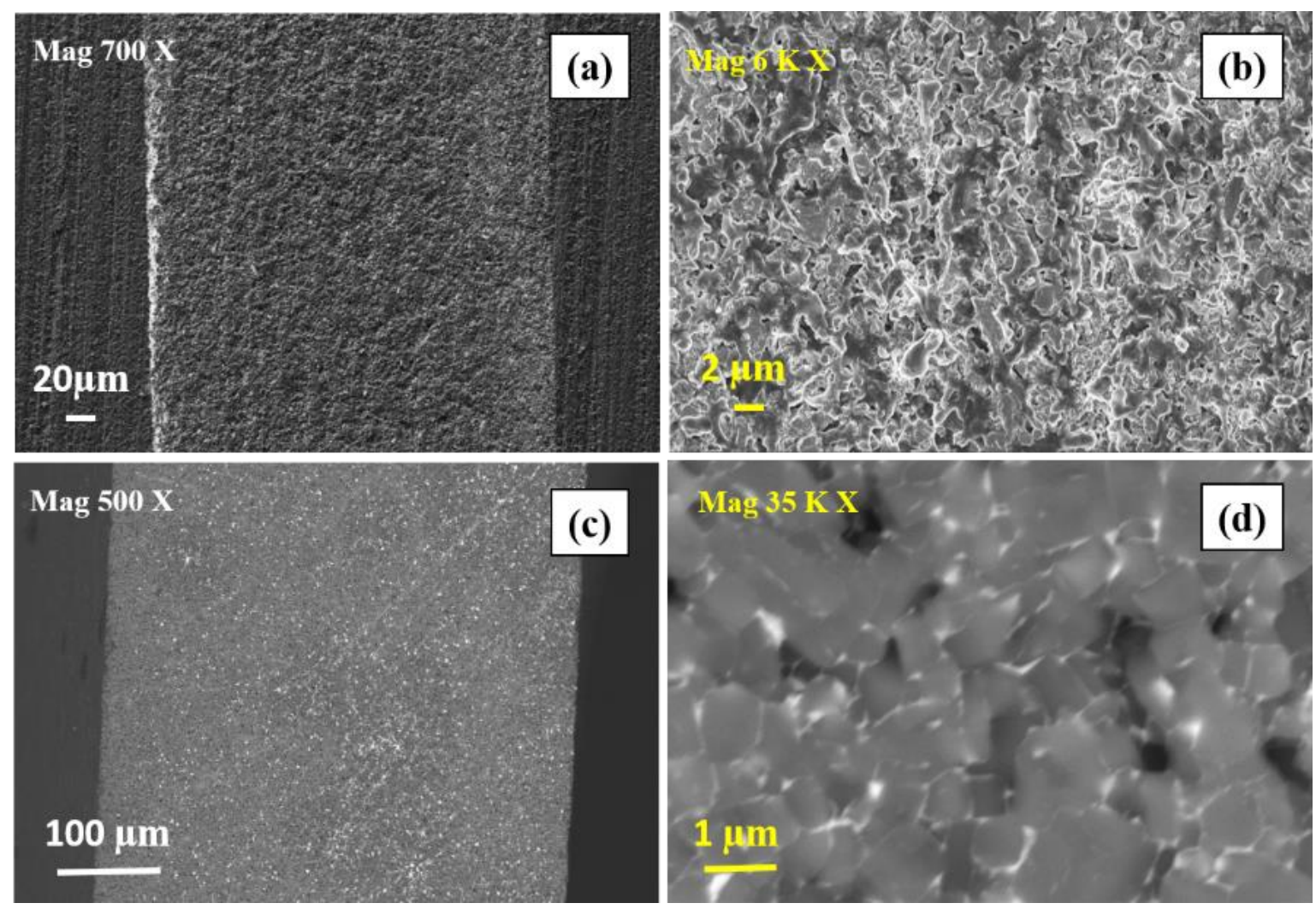

Fig. 3 

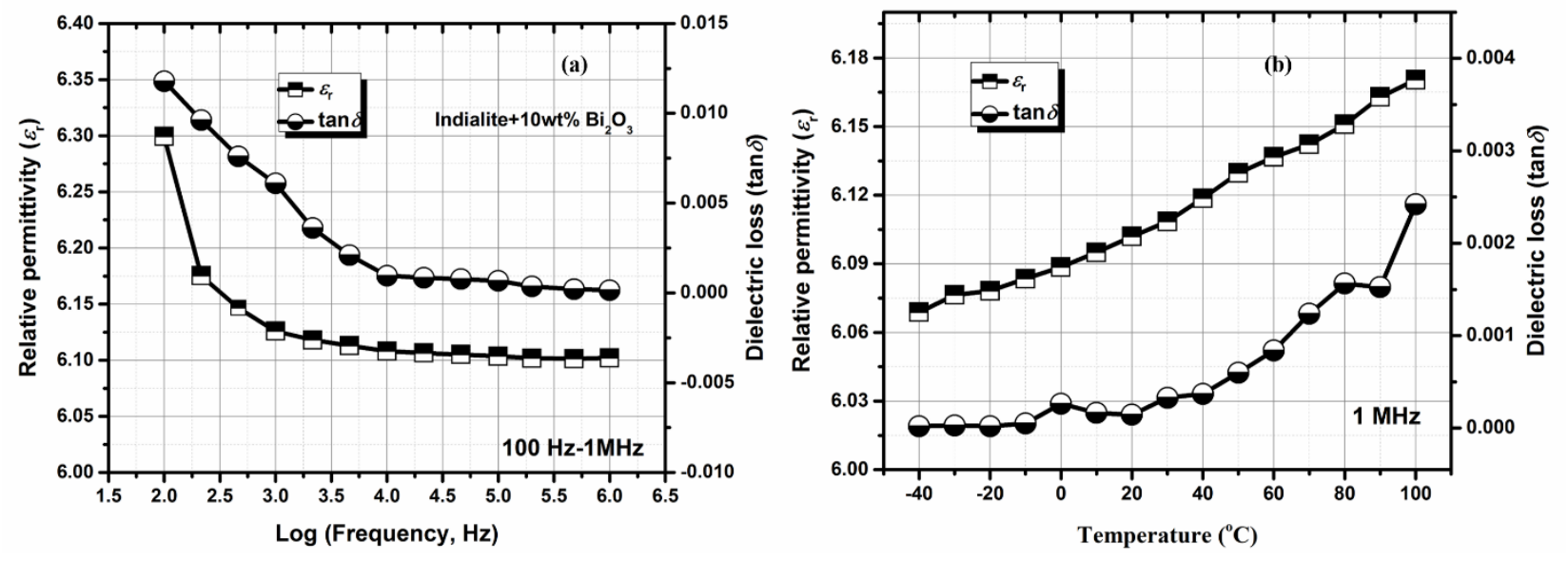

Fig. 4 


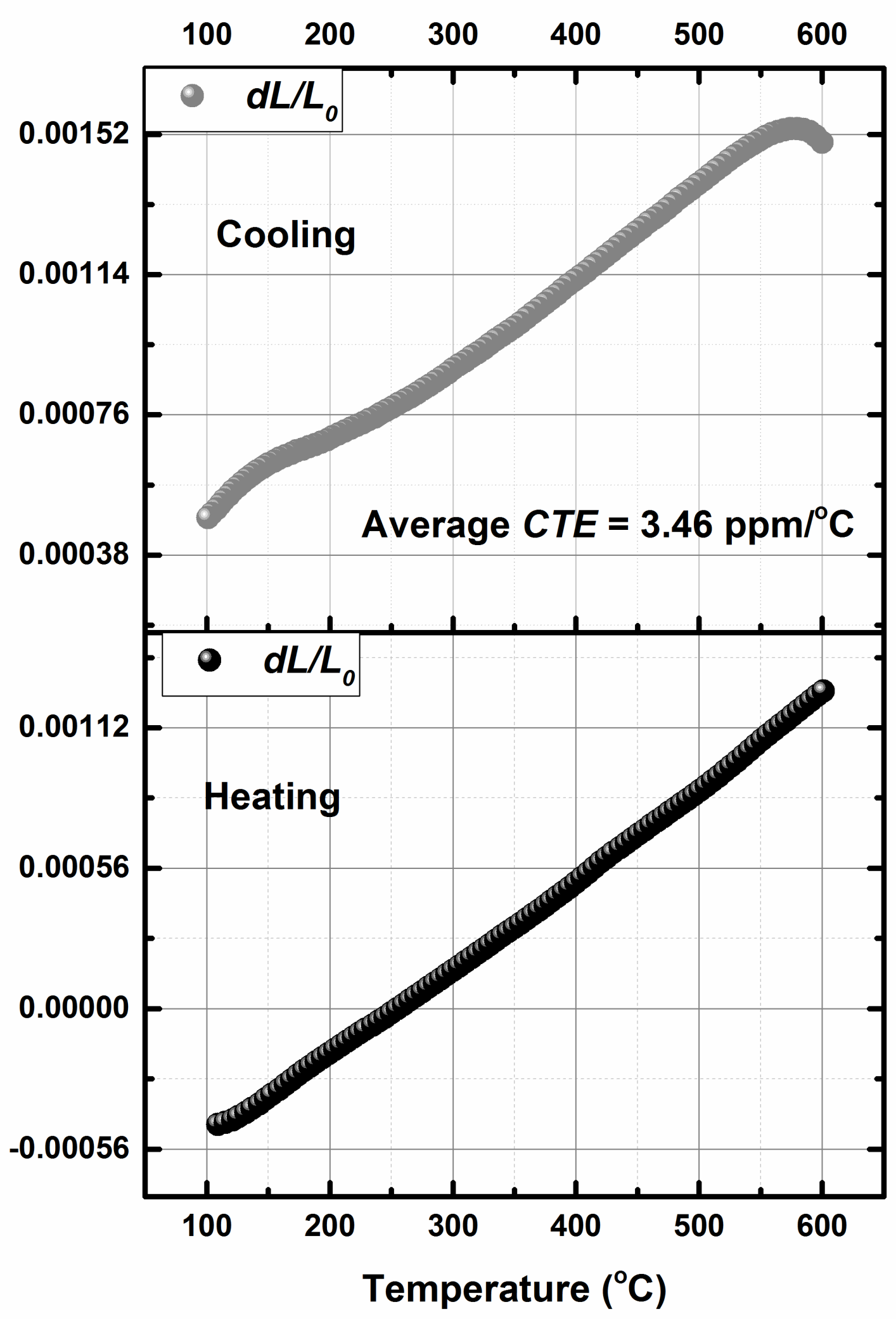

Fig. 5 
